Yu.V. Shabatura, B.O. Seredyuk, S.Z. Malynych, V.V. Atamanyuk

Petro Sahajdachnyj Academy of Land Forces, Lviv

\title{
THE EXPERIENCE OF ESTABLISHING AND EMPLOYING OF SPECIALIZED LABORATORY OF PHYSICS IN TEACHING PROCESS IN HETMAN PETRO SAHAYDACHNYI ARMY ACADEMY
}

\begin{abstract}
In present paper we summarize our experience in establishing and employing of specialized laboratory of Physics in the military college and/or university. Military character of the laboratory studies of a number of fundamental physical phenomena and interactions is demonstrated based on the analysis of various laboratory set-ups.
\end{abstract}

Keywords: laboratory classes, fundamental laws of Physics, military technical education.

\section{Problem formulation}

Physics course is a key discipline of the natural science component of a normative part of the training courses for cadets of all fields and specialties who study in hetman Petro Sahaydachnyi Army Academy (hereafter AA). Therefore, learning of Physics seems to be very essential, which along with such discipline as Calculus forms a fundamental basis of quality and successfulness of training of modern officer of the Armed Forces of Ukraine.

\section{Analysis of studies and publications}

Common experience as well as our own one demonstrates that full and accurate learning of Physics can be realized only with the use of a complex combination of lectures, practical, and laboratory classes in teaching process [1]. It is essential to provide professional direction of this discipline for military college, since a modern officer during his professional service is obliged to use different types of military devices whose construction and functioning is based exclusively on the laws of Physics, physical phenomena, regularities, and interactions of a material universe. For that reason a group of co-authors of the Department of Electro-mechanics and Electronics published corresponding textbooks $[2,3]$ that allow to provide lectures, practical and to some extend laboratory components of the teaching process in Physics. Meanwhile, the creative character of the young teachers of Physics of the Department of Electro-mechanics and Electronics stimulates to continuous search and design of new laboratory setups and devices, which allow cadets efficiently and clearly demonstrate manifestations of physical picture of modern universe and technologies.

The aim of this work is to share our experience in establishing and exploration of specialized laboratory of Physics for teaching purposes in hetman Petro Sahaydachnyi Army Academy.

\section{Basic statements}

In order to perform the laboratory course in Physics the faculty of the Department of Electromechanics and Electronics of AA with the active participation of the cadets of the Department of the Rocket Forces and Artillery constructed setups and test benches, that provide performing of more than 50 experiments, one-fourth of those are directly connected to military subjects. Let us discuss the most representing examples of the lab classes of military direction.

\section{Determining of the bullet speed by the use of ballistic pendulum}

Each of militaries must be familiar with the construction and functioning of fire weapon and be able to shoot accurately. Note that the range and efficiency of hitting completely depends on the initial speed of a bullet or missile. Therefore, laboratory studies aiming the determination of the speed of a bullet is substantial for future officers with regard to their professional service and important from the point of view of learning of the basic laws of mechanics, which form the basis of the modern Physics.

Aim of the experiment: determination of the speed of a bullet using ballistic pendulum.

Experimental setup: pump gun, ballistic pendulum, registration device. The setup is presented in Fig. 1.

In present work an indirect technique of the determination of the bullet speed based on inelastic collision is employed. The speed of a bullet at the edge of a barrel is the main ballistic parameter being used for calculations of its further trajectory. In this experiment the cadets are required to use such fundamental laws of Physics as energy and momentum conservation the mathematical expression of which provides to derive a final expression of the bullet speed.

The matter of the experiment is as follows. The shot from the pump gun results in inelastic collision with a motionless target of a mass greater than that of a 
bullet. After the collision the target starts to move while the ratio of its speed to that of a bullet is the same as a ratio of their mass. Schematics of the experiment along with the notation of valid measured parameters is presented in Fig. 2.

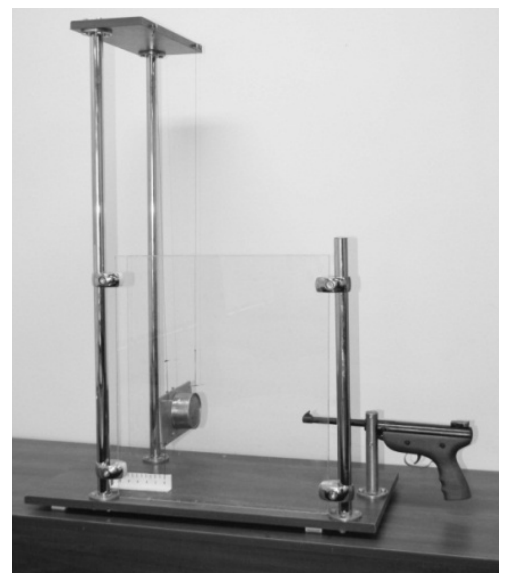

Fig. 1. Experimental setup

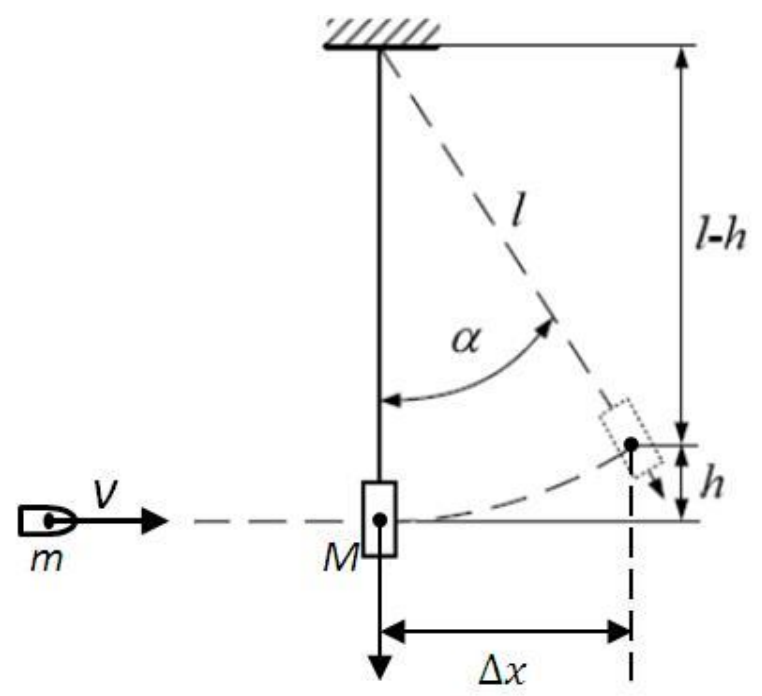

Fig. 2. Schematics of the experiment with a ballistic pendulum

The experiment is based on the momentum conservation law, which is applicable when the bullet hits a target as well as the energy conservation law that define the deviation of a pendulum on the angle $\alpha$. Neglecting the friction at the pivot point one can consider the pendulum as mathematical one. Therefore, the angle of deviation of the pendulum $\alpha$ after the shot can be calculated from known pendulum length and measured linear displacement $\Delta x$ as

$$
\sin (\alpha)=\frac{\Delta x}{l}
$$

Final expression for the determination of the speed of a bullet from the pump gun reads as

$$
v=\frac{2 \mathrm{M}}{m} \sqrt{\lg \sin }\left(\frac{\alpha}{2}\right),
$$

where $m$ is the mass of a bullet, $M$ is the mass of the pendulum, $l$ is the length of the pendulum, $g$ is the freefall acceleration. It is important to emphasize that the derived analytical expression is absolutely valid for the determination of the bullet speed shot from the firearms.

\section{Determination of the moment of inertia of a scale model of a turret using rotational pendulum}

The most defended and at the same time powerful weapon of a modern army are armoured vehicles among which the tanks are the most important. From the mechanical point of view the tanks can be considered to some extent as a physical body of a big mass capable for quick motion and comprise two parts, namely a hull and a turret. At the same time, the forces and the moment of inertia are significant, when the massive bodies are in motion. The officers should be able to calculate those parameters and take them into account when employing the machines. Therefore, laboratory studies when the cadets gain new knowledge and skills to determine the moment of inertia of a tank turret are of great importance.

The aim of this experiment is determination of the moment of inertia of a scale model of a tank turret using rotational pendulum.

Experimental setup: rotational pendulum, scale model of a tank turret, stop-watch, a set of weights, caliper, ruler. The experimental setup is presented in Fig. 3.

This work is aiming to lend the cadets fundamental knowledge on the theory of a rotational motion. It is wellknown that tank turret rotates by electrical engine therefore, its moment of inertia is necessary for simulating of the technical parameters of the engine. The engine is designed to provide fast rotation of a turret in a desired direction and stop the turret at the defined angle.

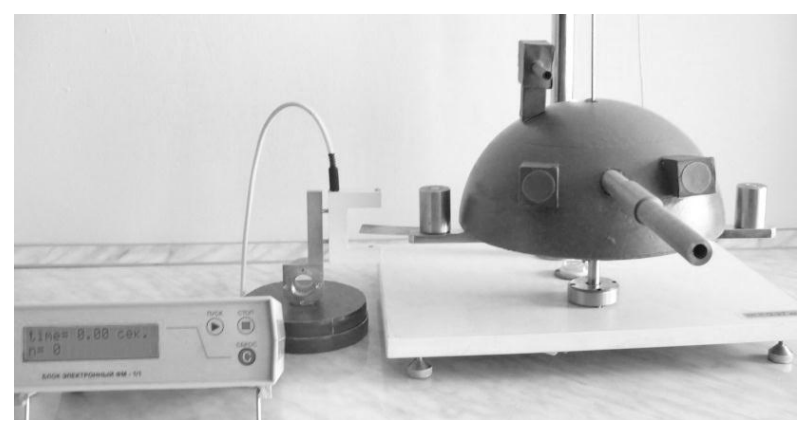

Fig. 3. Experimental setup

\section{Derivation of the final formulae}

The period of oscillations of unloaded scale model of a tank turret as a rotational pendulum reads as

$$
T_{1}=2 \pi \sqrt{\frac{J_{0}}{f}},
$$

where $f$ is the torsion modulus of the wire pendant, $J_{0}$ is the moment of inertia of a bar loaded with two weights.

$J_{0}$ can be determined as a sum of the moment of inertia of a uniform rod with regard to its middle axis 
and the moment of inertia of two weights at the distance of $x$ from the oscillation axis.

The moment of inertia of a rod reads as:

$$
J_{c}=\frac{m l^{2}}{12}=\frac{1}{12} \rho V l^{2}=\frac{1}{12} \rho a b l^{3},
$$

where $m=\rho V$ is a rod mass ( $\rho$ is the material density), $V=a b l$ is the volume of a bar with $a, b, l$ the dimensions of a rod.

The moment of inertia of the weights is expressed as:

$$
J_{T}=2 m_{T} c^{2}
$$

where $m_{T}$ is the mass of a single weight, $c$ is the distance from the center of a rotational pendulum to the center of the weight.

Therefore, $J_{0}$ can be defined as

$$
J_{0}=\frac{1}{12} \rho a b l^{3}+2 m_{T} c^{2} .
$$

The period of a rotational pendulum loaded with a scale model of a tank turret is

$$
T_{2}=2 \pi \sqrt{\frac{J_{0}+J}{f}},
$$

where $J$ is the moment of inertia of the model of a tank turret.

Via the simple transformations of the expressions for $T_{1}$ and $T_{2}$ one can define

$$
J=J_{0} \frac{T_{2}^{2}-T_{1}^{2}}{T_{1}^{2}} .
$$

Taking into account the expression for $J_{\mathrm{c}}$ final expression for the calculation of the moment of inertia of the model of a turret $J$ would be

$$
J=\left(\frac{1}{12} \rho a b l^{3}+2 m_{T} c^{2}\right) \frac{T_{2}^{2}-T_{1}^{2}}{T_{1}^{2}} .
$$

3. Determination of the speed of a bullet based on the inertial properties of a target

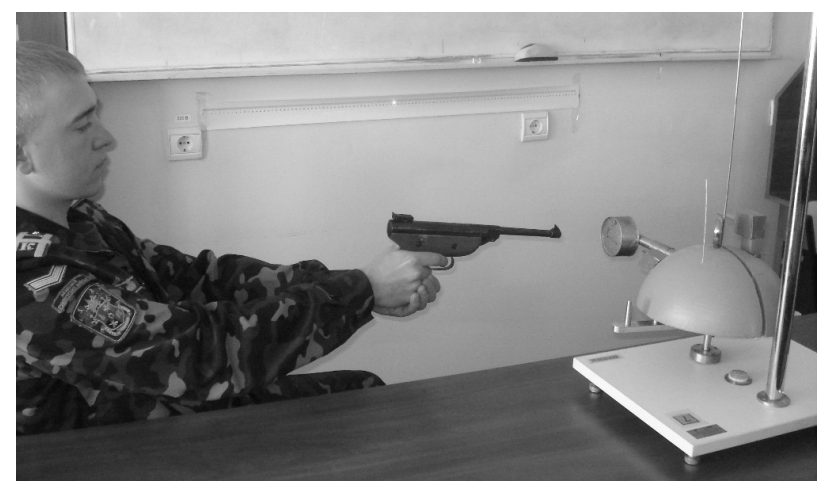

Fig. 4. Experimental setup

The aim of the experiment: to determine the speed of a bullet using rotational pendulum.

Experimental setup: rotational pendulum, scale model of a tank turret, stop-watch, a set of weights, caliper, ruler, pump gun, He-Ne laser.
This work is actually a combination of two previous ones. It intends to better understanding of knowledge gained from two previous experiments, namely the conservation laws presented in the first experiment as well as the laws of a rotational motion presented in the second experiment. In present work the cadets should use the value of the moment of inertia of the model of a turret determined in the second experiment and also compare the accuracy of the bullet speed determined in the first work. Laser beam is used to measure the angle of rotation of the pendulum with a high accuracy.

The angular momentum of the model of a tank turret $\boldsymbol{M}$ is connected to its moment of inertia via the expression

$$
\vec{M}=J \vec{\varepsilon} .
$$

According to the expression for the torque the speed of a bullet can be found from the expression

$$
v=\frac{M}{m} \cdot r \cdot \Delta t,
$$

where $m$ is the bullet mass, $r$ is the distance from the target to the center of rotation, $\Delta t$ is the time interval on which the bullet penetrates the target to the complete halt.

4. Measurement of the intensity of radioactive emission of the Strontium-Yttrium standard source

Nowadays nuclear weapon becomes so powerful that is capable of total destruction of the whole mankind. Despite this a priory statement is agreed in all countries, the world's nuclear arsenals exist and even increase. Therefore, experimental studies of the most dangerous elements of the nuclear weapon, namely ionizing radiation is very important in the training system of future officers.

The aim of the work: to measure of the radioactive emission of the Strontium-Yttrium standard source and to study of the radiation transmission through the obstacles.

Devices and experimental setup: dosimeter of the radiation emission, Strontium-Yttrium standard source, aluminum plates of various thickness. The experimental setup is presented in Fig. 5.

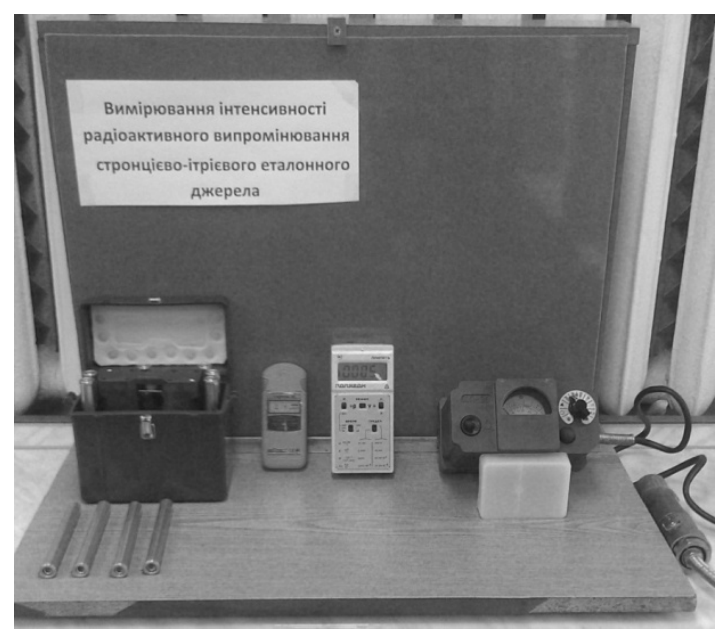

Fig. 5. Experimental setup 
Flux of the radioactive emission can be observed in some extraordinary situations and is studied in military realm. There are three types of radioactive emission, namely $\alpha, \beta$ and $\gamma$ ones. It is well known $[1,4]$ that $\alpha$ emission is a flux of Helium nuclei, $\beta$ is a flux of electrons, while $\gamma$ is the electromagnetic radiation of an extremely high frequency that is biologically hazardous.

In this work $\beta$ radiation of a Strontium-Yttrium source is studied. The source in a form of a liquid solution is sealed up into well screened ampoule. In order to better inform the cadets on the methods and facilities of the protection from the radiation impact the exponential decay of $\beta$ radiation when passing through the medium is studied. The exponential decay reads as

$$
I=I_{0} e^{-\mu x},
$$

where $I_{0}$ and $I$ is the intensity of $\beta$ radiation impinged on a surface of a medium and exiting from it respectively, $x$ is a thickness of the layer, $\mu$ linear absorption coefficient, which depends on the material properties and the energy of $\beta$ radiation. This work provides the cadets with fundamental knowledge on the transmission of radioactive emission through different types of materials

5. Measurement of the temperature of heated objects and determination of Stefan-Boltzmann constant

Fire-arms, that is more or less combined with explosives is the main power of modern Armed Forces of Ukraine. From the point of view of Physics the firearms act as a heat engine where thermal energy from the gunpowder burning and exothermal chemical reactions of the explosives is transformed into work. Obviously, one of the most important parameters in mentioned processes is the temperature. It is clear that contact methods of its measuring cannot be used. Moreover, measuring of high temperature of $800^{\circ} \mathrm{C}-3000^{\circ} \mathrm{C}$ by a hydrogen or alcohol thermometer is impossible. To measure high temperature without any contact with an object one can use optical pyrometer. Pyrometer is a device capable of measuring of the temperature of heated objects by the intensity of their thermal radiation in the visible spectral range. Pyrometer measures the power of thermal radiation of a heated object. Basics of the pyrometers are described in the Physics lectures course in the chapter "Quantum theory of radiation". Pyrometer is actually a prototype of thermal vision devices that have numerous military applications. Therefore, knowledge gained by the cadets during this work have military technical direction.

The aim of the experiment: to familiarize with the construction and functioning of a pyrometer, to measure the temperature of an incandescent filament and determine Stefan-Boltzmann constant.

Experimental setup: optical pyrometer, power unit, incandescent lamp, ammeter, voltmeter, voltage controller. Experimental setup is presented in Fig. 6.

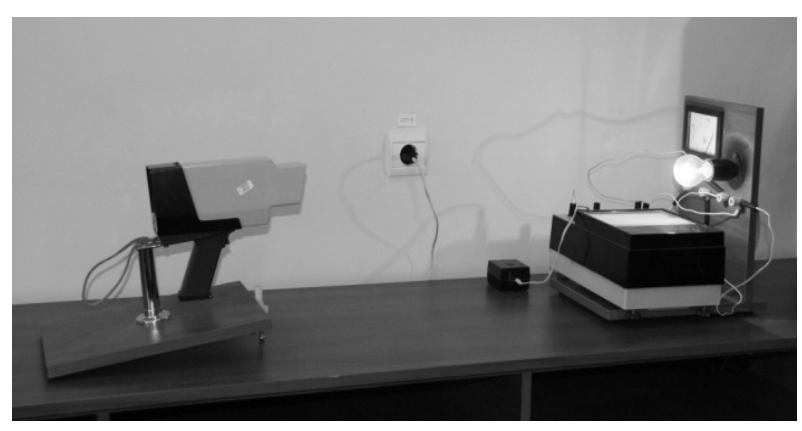

Fig. 6. Experimental setup.

To determine the Stefan-Boltzmann constant one can compare the power of the electric current used for heating up tungsten filament of an incandescent lamp and the power of thermal radiation emitted from the surface of the filament. The expression reads as

$$
P=I \cdot U=\alpha \cdot S \cdot \sigma\left(T^{4}-T_{0}^{4}\right),
$$

where $S$ is an area of the surface of tungsten filament, $\alpha=0.85$ is the emissivity of tungsten, $\sigma$ is the StefanBoltzmann constant, $T$ is the temperature of the filament, $T_{0}$ is the ambient temperature. The cadets are required to determine the Stefan-Boltzmann constant from the expression above and compare it with the value given in a handbook and prove experimentally that that the power emitted per unit area of the surface of a black body is directly proportional to the fourth power of its absolute temperature with the StefanBoltzmann constant as a proportionality coefficient.

\section{Conclusions}

More than six years of experience of the faculty of the Department of Electro-mechanics and Electronics of hetman Petro Sahaydachnyi Army Academy in designing of specialized laboratories and providing the teaching process in special technical disciplines as well as fundamental ones, Physics in particular, confirm following

1. Providing of high efficiency of learning Physics by the cadets under such circumstances as the lack of study time and specifics of a military college/university is only possible when the laboratory equipment is directly connected to the future military professional service;

2. All specialized laboratory equipment is designed based on module principle and possesses compact size and low weight that allow fast organization of physical experiments outside the laboratory just in any class;

3. Most of the equipment are unique and do not have analogs in other universities. All experiments are provided with detailed manuals where corresponding military applications are certainly noted and proved. This allows additionally increase the cadets' interest in a deep studying of physical laws, processes, phenomena, and interactions that are the basis of functioning of any military machines and armament. 


\section{References}

1. Korsunsky B. Physics Challenge for Teachers and Students / B. Korsunsky // Phys. Teach. - 2015. -Vol. 53, №124. P. 380-388.

2. Seredyuk B.O., Chikh V.I., Shabatura Yu.V. Military Physics. Textbook // B.O. Seredyuk, V.I. Chikh, Yu.V. Shabatura // Lviv: ASV. - 2014. - P. 340.

3. Shabatura Yu.V., Chikh V.I., Baran S.R., Serediuk B.O. Physics laboratory. Manual / Yu.V. Shabatura, V.I. Chikh, S.R. Baran, B.O. Seredyuk // Lviv: ASV. - 2011. - P. 244.
4. Yavorskiy B.M., Detlaf A.A. Handbook on Physics / B.M. Yavorskiy, A.A. Detlaf// Moscow, Nauka. - 1980. - P. 507.

Рецензент: д.т.н., проф. Б.І. Сокіл, начальник кафедри інженерної механіки, Академія сухопутних військ імені гетьмана Петра Сагайдачного, м. Львів.

\title{
ДОСВІД СТВОРЕННЯ І ВИКОРИСТАННЯ В НАВЧАЛЬНОМУ ПРОЦЕСІ АКАДЕМІЇ СУХОПУТНИХ ВІЙСЬК ІМЕНІ ГЕТЬМАНА П. САГАЙДАЧНОГО СПЕЦІАЛІЗОВАНОЇ ЛАБОРАТОРІЇ ФІЗИКИ
}

\author{
Ю.В. Шабатура, Б.О. Середюк, С.З. Малинич, В.В. Атаманюк
}

Узагальнюється досвід створення і використання спеціалізованої лабораторії фізики у вищому військовому навчальному закладі. На прикладах аналізу різних лабораторних стендів показана військова спрямованість лабораторних досліджень багатьох фундаментальних фізичних явищ і взаємодій.

Ключові слова: лабораторна робота, фундаментальні закони фізики, військово-технічне спрямування.

\section{ОПЫТ СОЗДАНИЯ И ИСПОЛЬЗОВАНИЯ В УЧЕБНОМ ПРОЦЕССЕ АКАДЕМИИ СУХОПУТНЫХ ВОЙСК ИМЕНИ ГЕТМАНА П. САГАЙДАЧНОГО СПЕЦИАЛИЗИРОВАННОЙ ЛАБОРАТОРИИ ФИЗИКИ}

Ю.В. Шабатура, Б.А. Середюк, С.З. Малинич, В.В. Атаманюк

Обобщается опыт создания и использования специализированной лаборатории физики в высшем военном учебном заведении. На примерах анализа различных лабораторных стендов показана военная направленность лабораторных исследований многих фундаментальных физических явлений и взаимодействий.

Ключевые слова: лабораторная работа, фундаментальные законы физики, военно-техническое направление. 